\title{
Possible acquired resistance of dogs successively infested by Amblyomma cajennense (Fabricius, 1787) (Acari: Ixodidae) nymphs
}

\author{
Possibilidade de ocorrência de resistência adquirida em cães sucessivamente infestados \\ por ninfas de Amblyomma cajennense (Fabricius, 1787) (Acari: Ixodidae) \\ Carolina Maria Vianna de Freitas ${ }^{1}$; Romário Cerqueira Leite ${ }^{2 *}$; Eduardo Bastianetto ${ }^{2}$; \\ Arildo Pinto da Cunha²; Ana Cristina Passos de Paiva Belo \\ ${ }^{1}$ Universidade Presidente Antonio Carlos - UNIPAC \\ ${ }^{2}$ Escola de Veterinária - EV, Universidade Federal de Minas Gerais - UFMG
}

Received July 24, 2008

Accepted September 8, 2009

\begin{abstract}
The present study aimed to evaluate the occurrence of immune resistance in dogs successively infested with Amblyomma cajennense nymphs. Five animals were submitted to four consecutive infestations with $A$. cajennense nymphs, at fourteen-day intervals. For each infestation, 50 nymphs were used per animal and data on the parasitic and non-parasitic periods were recorded. The average recovering rate of engorged nymphs in the successive infestations were 52.0, 29.2, 9.6 and $12.8 \%$, respectively, with a significant reduction $(\mathrm{p}<0.05)$ of this parameter from the second infestation onwards. The modal drop-off day of engorged nymphs was Day 4 of parasitism in all infestations. The average mortality rates of nymphs seen on the first, second, third and fourth infestations were 3.6, 3.2, 2.0 and 2.8\%, respectively, with no significant differences among them $(\mathrm{p}<0.05)$. In addition, no significant differences were seen among the ecdysis rates for specimens recovered from successive parasitic challenges. The study results suggest that the acquired resistance of infested dogs had a negative effect on recovery rate of $A$. cajennense nymphs; however, it did not affect the other biological parameters evaluated.
\end{abstract}

Keywords: Immune resistance, Amblyomma cajennense, Ixodidae, dogs.

\section{Resumo}

O presente trabalho teve por objetivo avaliar a ocorrência de resistência imune em cães, frente a infestaçóes sucessivas por ninfas de Amblyomma cajennense. Para tanto, cinco animais foram submetidos a quatro infestaçóes consecutivas por ninfas de $A$. cajennense em intervalos de quatorze dias. Foram aplicadas 50 ninfas em cada animal por infestaçáo e os dados referentes aos períodos parasitários e não parasitários, foram registrados. As taxas médias de recuperação de ninfas ingurgitadas, verificadas nas sucessivas infestações foram de 52,0, 29,2, 9,6 e 12,8\%, sendo observada uma redução significativa $(\mathrm{p}<0,05)$ nesse parâmetro a partir da segunda infestação. $\mathrm{O}$ dia modal de queda das ninfas ingurgitadas em todas as infestaçóes foi o $4^{\circ}$ dia de parasitimo. As taxas médias de mortalidade de ninfas observadas no primeiro, segundo, terceiro e quarto desafio parasitário foram de, respectivamente, 3,6, 3,2, 2,0 e 2,8\%, não havendo diferença significativa entre elas $(p<0,05)$. Não observou-se diferença significativa $(p<0,05)$ entre as taxas de ecdise reportadas para os exemplares recuperados nos sucessivos desafios parasitários. Esses resultados sugerem que a resistência adquirida nos cães parasitados afetou negativamente a taxa de recuperação das ninfas de $A$. cajennense inoculadas nesses animais, contudo não apresentou nenhum efeito sobre os demais parâmetros biológicos avaliados.

Palavras-chave: Resistência imune, Amblyomma cajennense, Ixodidae, cão.

\footnotetext{
*Corresponding author: Romário Cerqueira Leite

Laboratório de Ectoparasitoses, Escola de Veterinária - EV,

Universidade Federal de Minas Gerais - UFMG,

Av. Antônio Carlos 6627, CEP 30161-970 Belo Horizonte - MG, Brazil

e-mail: cleite@vet.ufmg.br

Supported by: CAPES; FAPEMIG and CNPq
} 


\section{Introduction}

In tropical regions, a vast variety of ticks infest dogs living either in urban areas, where Rhipicephalus sanguineus is the predominant species (SZABÓ et al., 2001; OYAFUSO et al., 2002), or in peri-urban and rural areas, where dogs are frequently infested with Amblyomma species, including Amblyomma cajennense (LABRUNA et al., 2000). This tick is popularly known as "star tick" or "rodoleiro" tick. Direct damages caused by this species in infested animals include cutaneous injuries, allergic reactions, blood loss and the potential to transmit infectious agents (O'DWYER et al., 2001). Furthermore, it should be emphasized its public health role, as $A$. cajennense is the main ixodide population infesting human beings. This tick species is a potential vector of Rickettsia ricketsii, the etiological agent of Rocky Mountain spotted fever in neotropical areas (GUEDES et al., 2005).

Despite all direct and indirect damages caused to domestic animals and man, the development of resistance in these hosts due to the parasitic challenge is likely to occur, through effector mechanisms of innate and acquired immune responses (CRAIG et al., 1996, BROSSARD; WIKEL, 2004). Such resistance develops after the first tick exposure and is, expressed in subsequent infestations by a decrease in number and body weight of engorged females, a decrease in number and viability of eggs, an increase in the engorgement period and mortality of ixodides during the feeding period on the host (BALASHOV, 1972; BROSSARD; WIKEL, 2004). These phenomena may limit tick ability to transmit infectious agents to their hosts, as they interfere directly in the parasitic process.

In a pilot study carried out in our laboratory in which dogs were repeatedly infested with $A$. cajennense nymphs, a certain level of resistance was seen after the second infestation onwards. These data contrasts with that reported in a similar study by Mukai et al. (2002) who did not find, this same immune resistance profile in dogs infested with $A$. cajennense nymphs.

Considering the close contact between man and dogs and the potential of dogs to disseminate ticks and consequently transmit diseases with zoonotic potential, it is important to describe the aspects involved in the interaction between dogs and $A$. cajennense nymphs. Thus, the present study aimed to evaluate the occurrence of immune resistance in dogs submitted to successive infestations by $A$. cajennense nymphs.

\section{Material and Methods}

The study was carried out at the Veterinary School, Federal University of the state of Minas Gerais, Brazil, from April to October 2005. The experiment was developed at the laboratory of endo and ectoparasitosis of the Department of Preventive Veterinary Medicine (DMVP) and DMVP animal nursery.

Five-months-old mongrel dogs (two females and three males), from two offsprings born in Belo Horizonte, Minas Gerais, were used for this experiment. Before initiating the experiment all dogs were vaccinated against hepatitis, distemper, parvovirus and leptospirosis, and were treated with antihelminthic drugs.

The study animals were kept isolated throughout the experimental period at DMVP animal nursery. They were kept in especially designed individual wire cages of $50 \times 60 \times 120 \mathrm{~cm}$. The cages were kept $40 \mathrm{~cm}$ above the floor in order to allow animal hygiene and keep the environment dry and comfortable. Water and commercial feed were offered ad libitum. The room was cleaned twice a day and included washing food and water containers and removal of feces and urine. In addition, the air-exhaust ventilation units were kept on for good air flow.

The ticks used in this experiment were obtained from two manual collections of engorged larvae from the body of an artificially infested horse, as described by Oliveira et al. (2003). These collections were carried out within a two-month interval, so that nymphs of approximately one month old were used to infest the study dogs. Engorged specimens were placed into plastic $3 \mathrm{~mL}$ plastic syringes that were previously prepared for the inoculation process. Syringes containing 50 engorged larvae were sealed with hydrophilic cotton and placed in an air-conditioned incubator $\left(27^{\circ} \mathrm{C}\right.$ and $80 \%$ relative humidity), and were monitored daily until completion of ecdysis. Only $A$. cajennense nymphs were used in the experiment.

Each dog was submitted to four consecutive infestations of 50 A. cajennense nymphs each, at fourteen-day intervals. On the day of infestation each animal was transferred to a $30 \times 40 \times 50 \mathrm{~cm}$ cage that was placed on a metallic tray, lined by double-coated adhesive tape to prevent dispersion of ticks. For infestation procedure nymphs was released on a piece of nylon carpet that was left inside the cage for 2 hours, following the modified technique as described by Young et al. (2003). After the required time for tick fixation, each dog was put back into its original cage. The trays and carpets were removed from the infestation cages and non-attached ticks were collected and counted.

After each infestation, the animals were monitored daily until complete drop-off of all ticks. Monitoring was carried out twice a day through visual inspection of attached parasites and manual collection of the detached ones. During this period, metallic trays lined by double-coated adhesive tape were placed under each dog's cage to recover naturally detached ticks. These trays were also inspected twice a day before the cages were cleaned up. The recovered nymphs were placed into Petri dishes, which were incubated as described before $\left(27^{\circ} \mathrm{C}\right.$ and $80 \%$ relative humidity), during the entire ecdysis period. For each infestation the following parameters were evaluated: mortality rate ${ }^{1}$, recovery rate of engorged nymphs ${ }^{2}$, modal day of nymph drop-off, and ecdysis rate of recovered nymphs ${ }^{3}$. Data analysis included ANOVA (analysis of variance) and means were compared through the Student's t-test at $95 \%$ confidence interval $(\mathrm{p}<0.05)$.

\section{Results and Discussion}

The biological parameters for recovered nymphs during the successive infestations are shown in Table 1.

The average recovery rates of engorged nymphs after successive infestations were 52.0, 29.2, 9.6 and 12.8\%. A significant decrease $(p<0.05)$ was seen in the mean number of ticks that were able to feed on dogs after the first infestation. This reduction may be

\footnotetext{
${ }^{1}$ Mortality rate $=($ no. of recovered dead nymphs $\div$ no. of inoculated nymphs $) \times 100$ ${ }^{2}$ Recovery rate $=($ no. of recovered engorged nymphs $\div$ no. of inoculated nymphs) $\times 100$

${ }^{3}$ Ecdysis rate $=($ no. of nymphs showing ecdysis $\div$ no. of recovered engorged nymphs) $\times 100$
} 
Table 1. Biological parameters (mean \pm standard deviation) of $A$. cajennense nymphs recovered after four successive infestations in dogs (Belo Horizonte, Brazil, 2005).

\begin{tabular}{|c|c|c|c|c|}
\hline \multirow{2}{*}{ Parameter (\%) } & \multicolumn{4}{|c|}{ Infestation } \\
\hline & First & Second & Third & Fourth \\
\hline Recovery rate & $52.0 \pm 6.8^{a}$ & $29.2 \pm 14.3^{b}$ & $9.6 \pm 5.9^{c}$ & $12.8 \pm 6.4^{\mathrm{c}}$ \\
\hline Ecdysis rate & $79.3 \pm 6.4^{\mathrm{a}}$ & $81.2 \pm 12.7^{a}$ & $90.0 \pm 22.4^{\mathrm{a}}$ & $87.6 \pm 14.0^{\mathrm{a}}$ \\
\hline Mortality rate & $3.6 \pm 2.2^{\mathrm{a}}$ & $3.2 \pm 4.1^{\mathrm{a}}$ & $2.0 \pm 1.4^{\mathrm{a}}$ & $2.8 \pm 2.4^{a}$ \\
\hline
\end{tabular}

a.b,c Means with no significant diference $(\mathrm{p}<0.05)$.

explained by the dogs' immune response on tick fixation sites, which can directly affect the feeding process of ticks or increase the animal's self-cleaning behavior, as an indirect consequence of that response (CRAIG et al., 1996). These results differ from those reported by Mukai et al. (2002) who did not find a significant difference on recovering rates of engorged $A$. cajennense nymphs after three successive infestations on dogs. It is possible that these authors' infestation method, which consisted of placing ticks in feeding chambers that were attached to the animal body, resulted in higher efficiency of inoculated nymphs. In contrast, in the present study, we tried to apply an infestation approach that was as closer as possible to the natural parasitic conditions, allowing natural grooming behavior, as expected in naturally infested animals.

Mean mortality rates of nymphs seen in the first, second, third and fourth infestations were 3.6, 3.2, 2 and 2.8\%, respectively, with no significant differences among them $(\mathrm{p}<0.05)$. Similarly, no significant differences were found $(\mathrm{p}<0.05)$ among ecdysis rates for specimens recovered from successive parasitic challenges (79.3, 81.2, 90.0 and 87.6\%). According to Balashov (1972), the minimum required weight to enable semi-engorged ixodides to undergo ecdysis corresponds to $20 \%$ of their normal weight after engorgement. Thus, probably almost all nymphs recovered in the present experiment were able to feed and reach the minimum required weight to undergo ecdysis to the next stage, even when conditions were not suitable for parasitism. This would explain the fact that ecdysis and mortality rates of recovered nymphs were not influenced by the development of immune resistance during successive infestations.

The modal day for drop-off of engorged nymphs for all infestations was Day 4 of parasitism.

Although ecdysis and mortality rates and the modal day for drop-off of $A$. cajennense nymphs were not influenced by the successive exposures of hosts to ticks, immune resistance of dogs was apparently the phenomenon causing significant decrease of recovery rates of engorged nymphs either through the development of a local inflammatory response or increasing grooming behavior of infested animals. However, further experiments using naïve dogs in each infestation are needed to confirm the occurrence of resistance; this would standardize and ensure the quality of nymph inocula.

\section{References}

BALASHOV, Y. S. Bloodsucking ticks (Ixodoidea) vectors of diseases of man and animals. Miscellaneous Publications of the Entomological Society of America, v. 8, n. 5, p. 337, 1972.

BROSSARD, M.; WIKEL, S. K. Tick immunobiology. Parasitology, v. 129, p. S161-S176, 2004.

CRAIG, L. E. et al. Acquired resistance and antibody response of raccons (Procyon lotor) to sequential feedings of Ixodes scapularis (Acari: Ixodidae). Veterinary Parasitology, v. 63, n. 3/4, p. 291-301, 1996.

GUEDES, E. et al. Detection of Rickettsia rickettsii in the tick Amblyomma cajennense in a new Brazilian spotted fever-endemic area in the state of Minas Gerais. Memórias do Instituto Oswaldo Cruz, v. 100, n. 8 , p. $841-845,2005$.

LABRUNA, M. B. et al. Ticks (Acari: Ixodidae) associated with rural dogs in Uruará, Eastern Amazon-Brazil. Journal of Medical Entomology, v. 37 , n. 5 , p. $774-776,2000$

MUKAI, L. S. et al. Development of resistance to nymphs of Amblyomma cajennense ticks (Acari: Ixodidae) in dogs. Annals of the New York Academy of Sciences, v. 969, p. 180-183, 2002.

O’DWYER, L. H.; MASSARD, C. L.; SOUZA, J. C. P. Hepatozoon canis infection associated with dog ticks of rural areas of Rio de Janeiro state, Brazil. Veterinary Parasitology, v. 94, n. 3, p. 143-150, 2001.

OLIVEIRA, P. R. et al. Seasonal dynamics of the Cayenne tick, Amblyomma cajennense on horses in Brazil. Medical and Veterinary Entomology, v. 17, n. 4, p. 412-416, 2003.

OYAFUSO, M. K. et al. Caracterização de carrapatos parasitas de cães em uma população hospitalar no norte do Paraná. Ciências Agrárias, v. 23, n. 1, p. 71-74, 2002.

SZABÓ, M. P. J. et al. Ticks (Acari: Ixodidae) associated with domestic dogs in Franca region, São Paulo, Brazil. Experimental and Applied Acarology, v. 25, n. 10/11, p. 909-916, 2001.

YOUNG, D. R.; ARTHER, R. G.; DAVIS, W. L. Evaluation of K9 Advantix $^{\mathrm{TM}}$ vs. Frontline Plus topical treatments to repel brown dog tick (Rhipicephalus sanguineus) on dogs. Parasitology Research, v. 90, n. 3, p. S116-S118, 2003. 